\title{
Promoting the Development of Women Through Literacy Education in Nigeria
}

\section{Dr Mabel Oyitso}

oyitsom@yahoo.com

\author{
$\operatorname{Dr}$ (Mrs) C.O. Olomukoro \\ Department of Adult and Non - Formal Education \\ University of Benin Benin - City
}

\section{Doi:10.5901/jesr.2014.v4n6p343}

\section{Abstract}

\begin{abstract}
Women's issues are global and universal. Illiteracy and limited access to education keep women marginalized. Literacy empowers and it is the most important means through which women can be developed socially, politically and economically. This paper, therefore, examines literacy and development and discusses how literacy education can help in the development of women. The paper goes further to highlight the benefits of literacy education to women and concludes with some suggestions on how women development can be enhanced.
\end{abstract}

Keywords: promoting, women, development, literacy and literacy education

\section{Introduction}

In all countries of the world, education is recognized as the cornerstone for sustainable development particularly for those who have been excluded from formal system of education and development. In the last two decades, according to Olaleye (2008), debates on the status of women and the need to integrate them into development process of any nation have ranged on at national and international workshops, seminars, and fora amongst others. The authors further stated that the problems of women opportunities for education looms larger at the turn of twenty-first century in Africa and that women represents two-thirds of the world illiterate adults while girls account for a similar proportion of the world's out-ofschool population. Corroborating this view, EFA Global Monitoring Report (2006) states that there are 771 million adult illiterates in the world today and two-third of them are women. For women to be integrated into development process, they need basic education, so that they can become co-partners in development.

The empowering role of literacy and its significance on development have been recognized world wide, noting that Nigeria, by 2006 national census figure has over 40 million illiterates of which 60 percent are women thereby placing Nigeria among the E-9 countries. The report further reveals that there are $71,709,859$ million males and $68,293,633$ million females in Nigeria. Two-thirds of the female populations are illiterate. From the foregoing, it is obvious that the level of education of women is low in Nigeria most especially in Northern parts of Nigeria. According to UNICEF report (2002), the national literacy rate for female was only 56 percent compared to 72 percent for male and in certain states; the female literacy, enrolment and achievement rate were much lower. For example, girls net enrolment in Sokoto State was 15 percent compared to 59 percent for boys. The Global Gender Gap Index 2010 shows that the gender gap in adult literacy rates for the period between 2006 and 2010 appears to be increasing instead of declining (See Table 1 below).

Table 1. Gender gaps in literacy rates in Nigeria, 2006-2010

\begin{tabular}{|c|c|c|c|}
\hline Year & Female & Male & Female/Male \\
\hline 2010 & 49 & 72 & 0.68 \\
\hline 2009 & 63 & 79 & 0.79 \\
\hline 2008 & 64 & 80 & 0.80 \\
\hline 2007 & 59 & 74 & 0.80 \\
\hline 2006 & 59 & 74 & 0.80 \\
\hline
\end{tabular}

Source: World Economic Forum, Global Gender Gap. Index 2010 Nigeria Profile. 
Although the situation might have improved, Nigerian women still have a long way to go in achieving gender parity. Hence the need for literacy programmes to be mounted up for women. As citizens of this country, women form a high percentage of the population, and as such they need quality literacy education to be able to contribute their quota to the development of the nation. There is now the realization that sustainable human development cannot be effective if half of the human race (the womenfolk) remain ignorant, marginalized and discriminated against (UNESCO 2002). The provision of quality literacy to nearly half of the population will greatly improve lives and livelihood and will no doubt have a great and sustainable social and economic impact on the womenfolk.

In this connection, various conferences and workshops have been held both locally and internationally and declaration pronounced to discuss and review the role women could play in development. The United Nations has been at the forefront of efforts to raise the status of women and bring them into the main stream of development. For instance, the International Women's Year (1975), the United Nations Decade for Women (1976-1985), the World Conferences held at Mexico (1975) Copenhagen (1980), Nairobi (1985) and Beijing (1995), have all contributed to promoting gender equality and women empowerment. This was based in its belief that the full integration of women in all aspects of political, economical and social life, at the international, regional and national levels, is essential if the obstacles to the achievement of the goals and objectives of the Decade for women are to be overcome (Okojie, 2011). Prominent among the conferences is the Fourth World Conference on Women held in Beijing, China in September, 1995. This was centred on equality, peace and development which called for equal participation and partnerships between men and women in nearly all areas of public and private life. The Beijing conference set the pace for progressive attention to gender issues in development. The end of women's decade was marked by the $3^{\text {rd }}$ World Conference on Women held at Nairobi in 1985 to review and reappraise the Decade's activities. The conference eventually adopted the Nairobi Forward Looking Strategies of Action for the Advancement of Women, up to the year 2000 (Fadeyi, 1995). Paragraph 163 of the United Nations Nairobi Forward Looking Strategies stated that "literacy an aspect of education is the basis for the full promotion and improvement of the status of women. It is the basic tool that should be given to women to fulfill their role as full members of the society". The importance of literacy in promoting gender equality and the advancement of women was further stressed by the Millennium Development Goals (2000), the Education for All (EFA) and Dakar goals (2000); Women Watch (2005).

On the Nigerian scene, the National Policy on Women was approved and adopted in April, 2000. The goal of the policy was the full integration of women into the social and political status as a means of developing the nation's human resources for national economic growth. Its objectives included the promotion of gender mainstreaming into all policies and programmes. The National Policy on Gender replaced the Women's policy, it was adopted in 2007. The policy is premised on recognition of gender issues as central to and critical to achievement of the goals and objectives of national development. Education, formal or non-formal has been seen as the foremost agent of empowerment. It is the bedrock of women empowerment. Moreover, education empowers women by improving their living standard. Access to literacy is considered one of the main factors for empowerment particularly empowerment of those excluded from formal system of education and development (cited in Olomukoro, 2012). Literacy provides access to written knowledge and knowledge is power. In a nutshell, literacy empowers, (Kassam, 1989). Studies have shown a direct relationship between literacy among women and improved health and childcare in the family as pointed out by Kagiticibais, Goksen and Gulgoz (2005). Extra year of education for mothers is associated with a significant decline in infant mortality and improved child health. It has been widely acknowledged that literacy is the key to women emancipation. As noted earlier in this write-up, women form a high percentage of the population and majority of them are illiterates, for them to be able to participate meaningfully and effectively in development process, they need quality literacy education. It is against this backdrop, that this paper examines women's development through literacy education. To achieve this objective, the paper is structured into five sections. The first section discusses the introduction, followed by the definition of development and the theoretical framework, developmental programmes for women, literacy as a tool for women development and benefits of literacy education.

\section{Development}

The concept of development has been viewed from different angles (for example, social, economic, political and cultural). Development, within the national outlook, depicts positive change or growth in socio-economic and political conditions or situations of the society. Development according to Akintayo and Oghenekohwo (2004) is a process of economic, social, political and cultural change engineered in a given society by the efforts of all stakeholders both internal and external. Osokoya (2008) perceived National development as the development of a nation's human and material resources and 
education is perhaps the only means to prepare individuals for participation in national development. In a similar vein, Ghai (1988), quoted in Fadeyi (1995), viewed development in terms of human potentials and capabilities in the context of relations with other social groups. The authors further emphasized that development means greater understanding of social, economic and political process, enhanced competence to analyse and solve problems of day-to-day living, expansion of manual skills, greater control over economic resources, restoration of human dignity, self respect and equality. The thrust is on the realization of human potential expressed in social emancipation and enhancement of moral, intellectual and technical capabilities. This is the kind of development women should crave for.

This view of development in terms of human potentials and capabilities lends credence to the Sen's theory of development and will form the theoretical framework for this write-up. Adult literacy has been recognized to play pivotal role in human development. Human development is defined as the process of enlarging a person's "functioning and capabilities to function, the range of things that a person could do and be in her life, expressed in the HDR as expanding "choice" (Amartya, Sen, 1989). Thus Sen's theory of development according to Parr (2003) is concerned with the expansion of capabilities which is the starting point of human development approach. The idea that the purpose of development is to improve human lives by expanding the range of things that a person can be and do, such as to be healthy and well nourished, to be knowledgeable, and to participate in community life. This development is about removing the obstacles to what a person can do in life, obstacles such as illiteracy, ill health, lack of resources, or lack of civil and political freedom. The 1990 HDR emphasized that "people are the real wealth of a nation". It goes thus:

Human development is a process of enlarging people's choices. The most critical of these wide ranging choices are to live a long and healthy life, to be educated and to have access to resources needed for a decent standard of living. Additional choices include political freedom, guaranteed human rights and personal self-respect

The 2001 HDR stated:

"The most basic capabilities for human development are to lead long healthy lives, to be knowledgeable, to have access to the resources needed for a decent standard of living, and to be able to participate in the life of the community.

The 1995 HDR stated:

"Human development is a process of enlarging the choices of all people not just for one part of society. Such a process becomes unjust and discriminatory if most women are excluded from its benefits.

From the foregoing, it is clear that the 1995 HDR on gender went beyond education, health and income outcomes to emphasize the importance of women's equal participation in political and professional life, their autonomy in decision making and the unequal sharing of unpaid work with men.

The 1995 Human Development Report which marked the fourth world conference on women in Beijing concluded that "human development is endangered except if it is engendered. Tadjbakhsh (2005) pointed out that the HDRs recognize that inequality is not only present in income or wealth, but also in basic rights such as freedom to enter contractual relations and decide on property; freedom to participate in public life and political leadership; freedom to receive training and participate in the labour market and freedom to live. and men in:

Thus, from the Human Development Reports, dimensions of gender equality relate to differences between women

Capabilities education and health

- Labour force participation

- Decision-making including participation in political decision-making

- Access to and power over economic resources (Okojie, 2011)

In the light of the above, development is seen as a multi-dimensional process involving the transformation and improvement of the economic, social and political situations of women.

\section{Development Programmes for Women through Adult Literacy and Non-formal Education}

Empowering women through adult literacy can be achieved effectively by designing and implementing well planned and organized literacy and non-formal education programmes. Serious emphasis on women empowerment was made in the year 2010. International Literacy day titled; World Literacy Day: Empowering Women through Literacy empowers us All. The UN secretary General Ban-Ki-Moon in his speech said that if women are empowered through literacy considering 
their multiple roles in the society will contribute greatly to the development of the nation. Women need greater access to educational opportunities, skill acquisition and positions of authority for them to be truly empowered. To this end, developmental programmes are designed to improve living conditions of women and to allow them participation in processes that will enhance their development at home, community and national levels. The main objective is to alleviate the burden of women daily lives through appropriate empowerment programmes (for example basic education, skill development, access to information regarding health, nutrition status, legal rights and so on).

In Nigeria, like other developing countries of the world, different programmes are embarked upon, sponsored by international organizations on national initiatives in collaboration with the state and local governments for the benefit of all women. In a bid to improve the welfare, the civic, political, cultural, social and economic development of women in Nigeria, the Decree No. 30 of 1989, which established the National Commission for Women was promulgated to formulate a national policy on women and development. All programmes for women are carried out by this Commission. The objectives of the Commission are to:

- $\quad$ promote the welfare of women in general;

- promote the full utilization of women in the development of human resources and to bring about their acceptance as full participants in every phase of national development, with equal rights and corresponding obligations.

- Promote responsible motherhood and maternal health of women;

- Stimulate actions to improve women's civil, political, cultural, social and economic education;

- Support the work of non-governmental organizations and to play a coordinating role between government and Nigerian women organizations;

- Encourage the sense and essence of cooperative societies and activities amongst women both in urban and rural areas and stimulate in them creative entrepreneurship in the field of cottage and small-scale industries.

- Formulate and propagate moral values within the family unit and in the public generally and to establish programmes with institutions and organizations to inculcate moral education in women and children; and

- Work towards the total elimination of all social and cultural practices tending to discriminate against and dehumanize womanhood.

In 1986, the Blueprint on Women Education in Nigeria was launched, followed by the setting up of women education units of Federal and State Ministries of Education. These units cater for both rural and urban women who desire to further their education. Attention is also focused on women with special needs such as nomadic and riverine women, women in pudah, dropouts of all categories, especially teenage single parents. The overall aim of the blueprint is to avail all women equal educational opportunities irrespective of their age, locality, creed or social status. The women education units also run women's vocational centres in all local government areas in the areas of cloth weaving, tie and dye, farming, food processing and preservation, dress making, cooking, cosmetology, secretarial, and computer studies.

The National Commission for Mass Literacy Adult and Non-Formal Education (NMEC) was set up in 1991 by the Federal Government, charging it with the task of eradicating illiteracy in the country. Women are specially targeted in the programmes of the commission with mass literacy classes being conducted in all nooks and crannies of the country. The 2008 EFA Global Monitoring Report states that more than 22 million people in Nigeria are illiterates; 65 percent of whom are women.

Many Christian and Muslim women's organizations are active in offering adult and non-formal educational opportunities to women; so are many other NGOs such as Officers' Wives Associations of Nigeria Armed Forces (Army, Navy, and Air Force). Similarly, many donor agencies such as UNICEF, UNESCO, UNDP, British Council, van Leer education Foundation, among others contributed enormously to various educational programmes for women in Nigeria. In the UNICEF/FGN Master Plan of Operation for the 1991-95 programme of co-operation, the education of women was identified as one of the areas of UNICEF's intervention. The plan states that: the education for women project will accelerate functional literacy attainment by enhancing access to and the quality of non-formal education for women of child bearing age. The project provided training in basic literacy and numeracy for women and girls training in basic income-generation and self-enhancing skills and promoted health awareness, including nutrition and safe motherhood among others (Ojobo, 2008). Furthermore, technical support for the nation's UBE programme and the use of radio for improving community education were made available by UNESCO. Also UNDP made fund available for the support of mass literacy programmes in some selected states of the federation.

Other programmes or projects undertaken by the federal government to strengthen girls' education with international development partners like UNESCO, World Bank, DFID among others are;

- provision of adult literacy and girls' education through the National Commission for Mass Literacy Adult and 
Non-formal Education (through education radio programmes, provision of supportive materials and awareness creation).

- Provision of library books to primary schools by the World Bank.

The United Nations Girls Education Initiative (UNGEI), which promoted the enrolment of more girls in school under the African Girls Education Initiative (AGEI) with financial support of the Norwegian government, was also put in place to promote women's status (Opeke, 2008). It is pertinent to note that, women's development can be greatly enhanced through active participation in the aforementioned literacy programmes and the application of the skills acquired thereby improving their livelihood and overall well-being.

\section{Literacy as a Tool for Women Development}

Literacy is not just the ability to read and write but also, according to the U.S. Department of Education (2007:2) the ability to use printed and written information to function in society, to achieve one's goal and to develop one's knowledge and potential. Akinpelu (2008) alluded to this view, that to be literate is not just to have mastered the skills of reading, writing and computing with numbers, but more than that, it is to be able to use those skills effectively for communications in all aspects of one's life in social, cultural, economic and political sphere. In addition, literacy as described in the LIFE document reads "literacy is an indispensable means for effective, social and economic participation contributing to human development and poverty reduction". Literacy empowers and nurture inclusive societies and contributes to the fair implementation of human rights. In case of mothers, literacy leads to an enhanced quality of life for their families and improved education outcomes for their children. It went further to state that literacy for all has to address the literacy needs of individual as well as the family. Literacy in the workplace and in the community, as well as in society and in the nation in tune with goals of economic, social and cultural development of all people in all countries" (UNESCO, 2005).

Research has shown a close link between education and development. Education, formal or non-formal, is increasingly seen as instrument of empowerment. National policy on women (2000) states that women's educational status in any nation correlates with its level of development. The higher the level of women educational status, the more developed the nation. The policy further asserts that "for Nigerian women to enjoy the full benefits of contemporary living and to contribute meaningfully to the development of the country, they require basic education. To further buttress the link between education and development, Imhabekhai and Olomukoro (2007) pointed out that literacy is a basic instrument in social transformation and modernization. It influences the rate of development and its possession or otherwise facilitates or retards the level of development. Similarly, Bhola (1983) in Sarumi (2005) states that without literacy, development limps on one leg. Literacy is seen as a veritable tool for all forms of developments efforts, including poverty alleviation. Adekola and Abanum (2010) argued that development cannot take place without education especially basic literacy. They maintained that development requires an educated and enlightened populace. This view was stressed by Aderinoye (2004), quoted in Adekola and Abanum (2010) that the difference between the developed and underdeveloped countries of the world is related to the level of literacy among the populace. A citizenry that can grasp what is happening in the global world and use that to better their society would contribute more meaningfully to the process of development than an illiterate who is ignorant of happenings in the global society. Literacy is a foundation on which education is built. Literacy is a sine qua non for development.

Women's literacy has gained greater prominence on political agendas over the past decade, ever since the world Education forum, in Dakar, at which governments set the goal of halving the number of illiterates by 2015. The United Nation (UN) Literacy Decade running from 2003 to 2012 has given further impetus to reducing, illiteracy (Ki-Moon, 2010) In addition; Boliva (2010) stated that investing in women's literacy carries very high returns: It improves livelihoods, leads to better child and maternal health, and favours girls' access to education. In short, newly literate women have a positive ripple effect on all the development indicators. The author further emphasized that literacy gives women a voice in their families, in political life and on the world stage. It is a first step towards personal freedom and broader prosperity. When women are literate, it is all society that gains.

At this juncture, we shall look at women and development in its various dimensions.

\subsection{Women and Social Development}

Research has shown a direct relationship between literacy among women and improved health and child care in the family. According to World Bank Report (2003), there is a strong positive association between mother's education and child mortality because low maternal levels of education result in poor child malnutrition and poor quality of care for 
children. The report further revealed that educated mothers are also more likely to educate their children, especially daughters, thereby increasing productivity and income of the next generation. Demographic Health Surveys show that child mortality is higher in households with less educated mothers.

From the foregoing, it is obvious that women need good quality basic education to enable them participate effectively in social development of their nation. Hence, Ramdas (1990) argued that increased female literacy is the key to development and this will ensure better child care, nutrition, the small family norm and promote better climate for learning. This is to say that a literate mother would be able to instill in her offspring the right attitudes and behaviour expected from them by the society.

\subsection{Women and Political Development}

Women who constitute a large proportion of the nation's population have important role to play in politics and nation building. Yet a large proportion of these women are illiterate and consequently, their level of participation is low when compared with the participation of men. In addition, cultural values which emphasize women's primary roles as wives and home makers are psychological barriers to women. As a result, women are less interested in politics and see politics as a man's world (Okojie, 2011) women should therefore be given basic education required to enable them participate in development process. Women should acquire a proper awareness of their potentials, rights and higher responsibilities in society. Basic literacy is the first step. The process of empowering of women cannot be complete until women themselves become active initiators and participate in political decision making. Nigeria scores low with respect to women's political participation. Participation in decision making within and outside the home is important if women are to influence decisions which affect their lives.

Table 2 shows that the representation of women in the National Assembly in Nigeria has been consistently very low and has not improved over time.

Table 2. Seats held in national assembly by year of election and gender

\begin{tabular}{|c|c|c|c|c|c|c|c|c|}
\hline & \multicolumn{2}{|c|}{1999} & \multicolumn{2}{|c|}{2003} & \multicolumn{2}{|c|}{2007} & \multicolumn{2}{|c|}{2011} \\
\hline Senate & Number & $\%$ & Number & $\%$ & Number & $\%$ & Number & $\%$ \\
\hline Men & 106 & 97.3 & 105 & 96.3 & 100 & 91.7 & 102 & 93.6 \\
\hline Women & 3 & 2.8 & 4 & 3.7 & 9 & 8.3 & 7 & 6.4 \\
\hline Total & 109 & 100.0 & 109 & 100.0 & 109 & 100.0 & 109 & 100.0 \\
\hline \multicolumn{9}{|c|}{ House of representatives } \\
\hline Men & 348 & 96.7 & 338 & 93.9 & 334 & 92.8 & 339 & 94.2 \\
\hline Women & 12 & 3.3 & 22 & 6.1 & 26 & 7.2 & 21 & 5.8 \\
\hline Total & 360 & 100.0 & 360 & 100.0 & 360 & 100.0 & 360 & 100.0 \\
\hline \multicolumn{9}{|c|}{ Both houses } \\
\hline Men & 454 & 96.8 & 443 & 94.46 & 434 & 92.5 & 441 & 94.0 \\
\hline Women & 15 & 3.2 & 26 & 5.54 & 35 & 7.5 & 28 & 6.0 \\
\hline Total & 569 & 100.0 & 469 & 100.0 & 469 & 100.0 & 469 & 100.0 \\
\hline
\end{tabular}

Source: NBS, 2009, and National Centre for Women Development

Out of the 109 seats in the National assembly in 1999, 2003, 2007 and 2011, women held 3,4,9 and 7 seats respectively translating to 2, 8, 3, 7, 8, 3 and 6, 4 percent compared with 97.2, 96.3, 91.7 and 94 percent recorded for men within the same period. The situation is similar in the House of Representatives.

The situation is similar in the state House of Assembly. Out of 990 seats in all states, women held only 24 in 1999 (2.4\%), 40 seats in 2003 (4.0\%); 57 in 2007 (5.8); and 56 in 2011 (5.6\%). Very few women are appointed committee chairpersons in parliament at all levels. Female representation is even less at the local government level 1.1\% in 1999, $2.9 \%$ in 2003 and 3.5\% in 2007 (NBS, 2009a). In general, women are grossly under-represented in leadership and key decision-making bodies at all levels federal and state legislatures, appointive positions, civil services, public enterprises and private companies (FGN, 2010a).

Women need more enlightenment and bolder action to actualize gender equality and women empowerment especially in the political arena. This can only be achieved through quality basic education. 


\subsection{Women and Economic Development}

Research studies and experience around the world show that literacy education has been found to have positive impacts on self-development and economic status - Education has been consistently shown to be a major determinant of individual income, along side professional experience as reported by EFA Global Report (UNESCO, 2006). Educated women are more able to engage in productive activities, find formal sector employment and earn higher wages, and enjoy greater return to their education than the less educated women. In addition women have limited access to productive resources such as land, credit and wage employment. Women rarely have titles to land and cannot use them as collateral to obtain credit as pointed out by Okojie (2011). Table 3 shows the gender gaps in labour force participation and earned income, 2010.

Table 3. Gender gaps in labour force participation and earned income, 2010

\begin{tabular}{|c|c|c|c|c|c|c|}
\hline & \multicolumn{3}{|c|}{ Labour Force Participation } & \multicolumn{3}{c|}{ Estimated Earned Income (US\$) } \\
\hline Year & Female & Male & F/M Ratio & Female & Male & F/M Ratio \\
\hline 2010 & 45 & 85 & 0.53 & 1,163 & 2,777 & 0.42 \\
\hline 2009 & 47 & 86 & 0.54 & 1,054 & 2,650 & 0.40 \\
\hline 2008 & 47 & 86 & 0.54 & 652 & 1,592 & 0.41 \\
\hline 2007 & 39 & 72 & 0.55 & 669 & 1,628 & 0.41 \\
\hline 2006 & 40 & 75 & 0.53 & 614 & 1,495 & 0.41 \\
\hline
\end{tabular}

Source: World Economic Forum, Global Gender Gap Index 2010 Nigeria Profile

One of the strategic objectives of the Beijing platform of Action (1995), Objective F.I. demands that governments "promote women's economic rights and independence including access to employment, appropriate working conditions and control over economic resources". The 2008 Demographic and Health Survey showed that the female labour force participation rate was $59.1 \%$ while that for males was $81.8 \%$. Employment data shows that women are predominantly engaged in agriculture and sales occupations. There is also over-representation of women in lower paid employment. Majority of Nigerian women are in self employment in the urban informal and agricultural sectors according to National Bureau of Statistics (2009a).

The gender gap in estimated earned incomes is as a result of gender gap in education. The table shows that there was no improvement in the ratio of female to male earned income over the period for which the Global Gender Gap Index has been computed. This implies that women are not benefiting significantly from access to education with respect to their labour market incomes. Government policy should therefore target improved access to education especially tertiary education which basic education is of course a prerequisite which will definitely yield higher returns and access to decent jobs where they can earn decent wages. Similarly, policies should also target women in the informal sector with training (entrepreneur food process) to increase their productivity and incomes.

From the foregoing, women need literacy education to be able to face the challenges ahead of them and also to enable them contribute their quota in the socio-political and economic development of the nation. That may be why Mangvwat (1995:176) indicated that empowering women and promoting their active involvement in development process requires political and economic goodwill to establish an enabling environment (which is literacy education) for their full participation.

\section{The Benefits of Literacy Education on Women}

The society and the family tend to gain from a literate woman. In other words, when women are literate, it is all society that gains. Literacy education is seen as a powerful agent of socialization in that it plays a tremendous role in preparing an individual to tender active and useful service both to the family and society in general. Literacy gives women a voice in their families, in political life and on the world stage. It is a first step towards personal freedom and broader prosperity (Bokova; 2010). The advantages of a literate woman can be seen in the life of the family, the economic and political life of the society. 


\subsection{Social Benefits}

Literacy has been found to have large social benefits; such as increased life expectancy, reduced child mortality, raising healthy children and educating them. Literacy is at the core of education and especially education for all with its focus on basic education. Literacy pave the way for further learning and, as stated in Article 1 of the World Declaration on Education for All Jomtein, Thailand, 1990 and reiterated in Dakar; Senegal (2000) Literacy and numeracy are essential learning tools of basic education. A Child denied the right of a quality primary education is deprived not only as a child; he/she is also handicapped for life-unable to cope with situations requiring reading, writing and arithmetic unless given access to educational opportunities as a youth or adult. Educated mothers are more likely to send their children to school than the uneducated ones.

Studies have shown that increase in female schooling have been followed by declining child mortality and fertility in subsequent decades. In general, the associations of female schooling with birth and death rates are among the most regularity uncovered by quantitative social science (Hobcraft, 1993; Jejeeboy 1995, United Nations, 1995).

In addition, a literate woman is exposed to the various media, an avenue where the government can reach women. Women can also help government to achieve its laudable goals and objectives through public enlightenment and national mobilization campaigns. In general, literacy education wipes away ignorance, political apathy and encourages mutual understanding and cooperation among the various strata of society.

\subsection{Economic Benefits}

The most important measurable forms of economic benefits include employment, earnings, enhanced general productivity, consumption behaviour, fiscal capacity (including tax revenue and the demand for social services), and intergenerational effect. One of the most consistent correlations in social sciences is between increased literacy skills and the probability of employment. Literacy properly designed and provided, is understood to impart skills and knowledge to participants that make them more productive in self-employment or in employment by others (UNESCO, EFA Global Monitoring Report; 2006).

The role of women in the economic development of the nation cannot be overemphasized. They constitute $70 \%$ of the group that produces food for the nation. They cultivate and grow food to feed the family and the nation at large. Studies in Nigeria and indeed in other parts of the world show that literacy education can help women increase productivity in wage employment where they work fewer hours and earn higher incomes and in the long run reduce poverty. Women when literate are also able to participate in self employment and in the informal sector which in turn leads to higher wage earning, more access to credit and production of goods for home consumption (Safo 1992, Morna 1999, Okojie 1997 and Abbe - Momudu 1999). In her contribution, Efedi (2008) said literate women create income or wealth for the family through their good and benefiting employment whether in private or public sector.

\subsection{Political Benefits}

The empowering potential of literacy can translate into political participation and thus contribute to the quality of public policies and to democracy. The relationship between education and political participation is well established. Educated people are to some extent more likely to vote and voice more tolerant attitudes and democratic values (Hannum and Buchman; 2003). According to Burchified (2002), Among Nepalese women, those who had spent two years in state run literacy programmes demonstrated more political knowledge than those not in the programmes and were more likely to believe they could serve as political representatives. In addition, Egbo (2000) reported that literate women in Nigeria for example, reported confident enough to participate in community meetings, unlike illiterate women.

Literate women have been known to contribute to the political stability and peace of a country. Examples have been those of late Mrs Indira Ghandi of India, Mrs Bandara Vaile of Sri Lanka, Mrs Acquino of Phillipines, Margaret Thatcher of United Kingdom and of course the first African woman president Sir Leaf Ellen Johnson elected in 2005 in Liberia (Gbadamosi 1986: 3, Efedi 2008: 72). These women ensured the political stability of their country during their time. Notable women in Nigeria have contributed to the political development and raising the consciousness level of their fellow women. In Nigeria, we have women in the various States house of Assembly, House of Representatives and Senate all for the good of the nation. There are also women in leadership positions who have made impact in the lives of Nigerians. Such women like Professor Dora Akunyili of former NAFDAC director and her fight against fake drugs, a fight that no man had dared or had the courage to do and also the former minister of information. Dr Ngozi Iweala and her 
dynamic reforms and leadership qualities in the finance sector. Dr Oby Ezekwezeli, Mrs Chinwe Nora Obaji, one time Minister of Education who initiated the policy on Post Jamb Test in 2006 (Okolin 2007). The above mentioned women were able to contribute their quota to the development of the nation because they were literate. Hence, Kassim Eghiator (2005) stressed the fact that educated women participated in politics and were able to contribute their knowledge to national unity, reconstruction and development.

From the above benefits, it could be seen that the education of women had made ineffective the traditional belief that the place of the woman is the home. We have also seen that in this jet age, women have been a force to reckon with in the political and socio-economic life of the nation. The role of women has gone beyond the four walls of their home and extends to all spheres of human endeavours in the development of the nation.

\section{Recommendations}

The following recommendations are put forward for the promotion of women literacy acquisition and development.

- First and foremost, the process of empowering the Nigerian woman and thus integrating her into the mainstream of the development must start from the early stages and from the grassroots. Parents, guardians, and the society as a whole must allow and encourage their female children to enroll in schools, overcome the paralysis of illiteracy and acquire a proper awareness of their potentials, rights and higher responsibilities in society.

- Expansion of quality primary and lower secondary education and scaling up of Adult and youth literacy programmes should be vigorously pursued.

- Literacy programes should be incorporated with life skills components so that women can be well equipped to perform their roles more effectively. Programmes relevant to the needs of the women should be promoted. In addition to functional skills, programmes that promote leadership skills, gender consciousness raising and emancipatory goals among women should be put in place.

- Awareness creation programmes should be intensified on the value of women education by the media in order to raise the consciousness of the illiterates especially at the grass root level.

- Qualified Adult literacy facilitators should be trained and facilitators stipends should be enhanced to boost their morale

- Budgetary allocation to Adult literacy programmes should be increased.

\section{Conclusion}

This paper has examined how literacy education could enhance women's development socially, economically, politically through appropriate empowerment programmes like basic literacy, skills acquisition and access to information regarding health, nutrition status, and legal rights and so on. Education formal or non-formal is the foremost agent of empowerment. Women educational status in any nation correlates with its level of development. The higher the level of women educational status the more developed the nation. Therefore, government, international development partners, civil society, non-governmental and private organizations should ensure that the use of literacy education programmes towards women development takes higher priority attention.

\section{References}

Abdu, R. (1993). The Mystery of Women. The Guardian, Lagos. Guardian Newspaper Ltd, Thursday February. 27.

Adekola, G., \& Abanum, B. (2010). Adult literacy for Rural Development in Rivers State, Nigeria. A paper presented at the annual National Conference of Nigeria National Council for Adult Education (NNCAE) held at the University of Ibadan, Ibadan.

Akintayo, M. O., \& Oghenekohwo, J. E. (2004). Developing Adult Education and Community Development. New Paradigms. Education Research Group.

Ban, K. (2010). World Literacy Day. Empowering women through literacy empowers us All. Fortune World News 8.

Bhola, H. S. (1994). Women's Literacy: A Curriculum of assertion, resistance and accommodation. Convergence, XXVII, (2/3).

Boliva, I. (2010). A paper delivered on the occasion of the International Literacy Day, Sept 2010. Adult and Non-formal. A Quarterly Newsletter of the National Mass Education Commission, Nigeria.

Burchfield, S., Hua, B. D., \& Rocha. (2002a). A longitudinal study of the effect of Integrated Literacy and Basic Education Programmes on the Participation of women in social and economic development in Nepal. Boston Mass, World Education: Washington, D.C. United States Agency for International Development office of women in Development. 
Efedi, O. E. (2008). Women Education: A Vehicle for Women effective and efficient role performance in national development in Nigeria; Benin Journal of Gender Studies, 1(1), 66-75.

Egbo, B. (2000). Gender, Literacy and Life. Chances in sub-Sharan Africa. Cleveland.Buffalo/Sydney, Multilingual Matters.

Fadeyi, O. T. (1995). The Impact of Literacy and Non-formal Education on Women Empowerment in Oyo State of Nigeria. An unpublished Ph.D Thesis: University of Ibadan.

Gbadamosi, A. A. (1986) Educate a woman, you educate a nation, A paper presented at the workshop to prepare a blue print on Women Education 23rd-26th September.

Hannum, E.. \& Buchman, C. (2003). The Consequences of Global Educational Expansion, Cambridge, Mass, American Academy of Arts and Sciences.

Hobcraft, J. (1993). Women's Education, Child Welfare and Child Survival: A review of the Evidence. Health transition Review, 3, 159175.

Imhabekhai \& Olomukoro. (2007). Integrating the Nomads into National Development Programme through Adult Education. In A. Nwazuoke, E. A. Okediran, \& O. A. Moronkola (Eds), International Journal of forum for African Women Educationists Nigeria (pp. 42- 48). Education for Social Transformation, University of Ibadan Printery.

Jejjebkoy, S. (1995). Women's Education. Autonomy and Reproductive Behaviour: Experience from Developing countries. Oxford: Clarendon Press.

Kagitabasi, C., Goksen, F., \& Gulgoz, S. (2005). Functional Adult Literacy and Empowerment of women: Impact of a functional literacy program in Turkey. Journal of adolescent and Adult Literacy, 48(6), 472-498.

Kassan, Y. (1989). Who Benefits from Illiteracy?. Literacy and Development in Prospects, 9(4), 531-535.

Kassim-Eghiator, F. E. (2005). Culture as a constraint in Women Education. A study of Ukwuani Women in Delta State.

Mangvwat, J. (1995). Socio-Economic and Political Perspective in Theory and Practice of Adult Education and Community Development in developing Countries. Women and Development (pp. 172-176). Lesotho German Association.

Ojobor, J. A. (2008). Education; a catalyst for women empowerment Ethiope. Journal Education and Science, 4(1).

Okojie, C. E. E (1992) Trends in Women Education in Nigeria: Stagnation Progress or Revolution in S.O. Oriaifo \& Gbenedio, U. B. (eds). Towards Education in Nigeria for the $21^{\text {st }}$ Century. Institute of Education (pp. 62-64). University of Benin, Benin City.

Okojie, C. E. E. (2011). Achieving Gender Equality and Women's Empowerment in Nigeria: should women wait in Hope or Expectation? Inaugural Lecture Series 120. University of Benin, Benin City, Nigeria.

Olaleye, F. O. (2008). Empowering Women through Education. In M. Boucouvalas \& R. Aderioye (Eds) Education for Millennium Development. Essays in Honour of Professor Michael Omolewa.

Olomukoro, C. O. (2012). Influence of Literacy Education Programmes on Socio-economic and Psychological Empowerment of Women in Edo and Delta States, Nigeria, An unpublished Ph.D Thesis. University of Ibadan, Ibadan.

Opeke, R. (2008). Gender in Nigeria education. An essay in honour of Michael Omolewa, a Professor of Adult Education, University of Ibadan, in M. Bouconvalas and R. Aderinoye (Eds) Education for Millennium Development, Vol. II.

Osokoya, I. O. (2008). Towards maximizing Women's contribution to National Development through Education in Nigeria in M Boucouvalas and R. Aderinoye (eds) Education for Millennium Development. Essays in honour of Professor Michael Omolewa, Ibadan, Spectrum Books Ltd, (II), 68 - 76.

Parr, S. F. (2003). The Human Development Paradigm: Operationalizing. Sen's Ideas on Capabilities. Feminist Economics, 9 (2-3), $301-$ 317.

Ramdas, L. (1990). Women and literacy. A quest for justice Convergence, XXIII(1), 27-41.

Salami, A. (2005). Mass literacy Efforts in the Pre-and Post Independent Nigeria: Some lessons from Adult Education History research. Nigerian National Council for Adult Education, 432-42.

Sen, G. (1993). Women's Empowerment and Human Rights: The challenge to Policy. Paper presented at the population summit of the world's Scientific Academies.

Tadjbakhsh, S. (2005). Contextualizing Gender Within Human Development. Gender Mainstreaming Training, UNDP Belarus, October 10-11.

UN. (1995). World Summit for social Development, Copenhagen 1995. UN Social Policy and Development Division (DESA)

UNESCO Education for All Global Monitoring Report (2006). Literacy for Life. Paris: UNESCO.

UNESCO Education for All Global Monitoring Report (2008). Education for all 2015. Paris: UNESCO.

United Nations. (1985). Nairobi forward Looking Strategies for the Advancement of Women.

Women Watch. (2005) Information and Resources on gender equality and empowerment of women. Education and Training of women and the girl child sponsored by UNESCO and UNICEF, 10 th January-4th February, 2005 moderated by UNESCO. 